\title{
FIRST RESULTS OF CLARIFYING OF ORBITAL ELEMENTS OF LOW-ORBIT SPACECRAFT USING OBSERVATIONS OF THE RI "MAO" DOPPLER STATION
}

\author{
V.Kriuchkovskyi, F.Bushuev, M.Kaliuzhnyi, M.Khalaley, M.Kulichenko, O.Shulga \\ Research Institute "Mykolaiv Astronomical Observatory" (RI "MAO”) \\ Mykolaiv, Ukraine,dir@mao.nikolaev.ua
}

\begin{abstract}
Earth, which emit radio signal at a frequency of $430-440 \mathrm{MHz}$ during their flight in the Mykolaiv visibility zone, were found as a result of the searching carried out in the RI "MAO". 10 of 18 satellites during not less than 7 days each were automatically tracked by the Doppler station created in the RI "MAO". The frequency of received radio signal was automatically determined as a result of spectral processing of radio signal amplitudes registered by the station during satellite tracking. Herewith 5 of 10 satellites emitted non-harmonic broadband signals. The radial velocity of satellites is calculated using the frequency of received radio signals.

The obtained values of radial velocity changing in time were used to clarify TLE (Two-Line Element) orbital elements of satellites. Initial orbital elements were downloaded from the space-track.org site. It would be noted that model values of Doppler shift of frequency, obtained using the initial orbital elements, also use for searching radio signals emitted by tracked satellites and received by the station. The regular (mean) and random (standard deviation) components of the difference $(\mathrm{O}-\mathrm{C})$ of measured and model values of radial velocity were calculated. A comparison of the regular and random components of O-C was made, which showed their slight decreasing after clarifying orbital elements.

In order to improve the accuracy of the orbit determination, it is proposed to upgrade the station's hardware and software in order to reduce synchronizing and frequency determination errors. It is also proposed to use more accurate models as Doppler measurements, and the motion of satellites.
\end{abstract}

АНОТАЦІЯ. В результаті проведеного в НДІ «МАО» пошуку виявлено 18 штучних супутників Землі, які при прольоті в зоні видимості Миколаєва випромінюють радіосигнал на частоті 430-440 МГц. Допплерівською станцією, створеною в НДІ «МАО», в автоматичному режимі проведено супроводження 10 iз 18 супутників протягом не менше, ніж 7 діб кожен. Частота прийнятого радіосигналу визначалася в автоматичному режимі в результаті спектральної обробки амплітуди сигналів, зареєстрованих станцією під час супроводження супутників. При цьому із 10 супутників 5 випромінювали негармонічний широкосмуговий сигнал. За частотою прийнятого радіосигналу обчислювалася радіальна швидкість супутника.

Отримані значення радіальної швидкості, що змінюються у часі, використовувалися для уточнення елементів орбіти супутника в форматі TLE (Two-Line Element). Початкові значення елементів орбіти завантажуються $з$ сайту space-track.org. Зауважимо, що модельні значення допплерівського зсуву частоти, отримані з використанням початкових елементів орбіти, використовувалися також для пошуки радіосигналів, випромінюваних супутником і прийнятих станцією. Обчислювалися регулярна (середнє) та випадкова (СКП) складові різниці (О-С) виміряних і модельних значень радіальної швидкості. Проведено порівняння регулярної і випадкової складових О-С, яке показало незначне зменшення регулярної і випадкової складових О-С після уточнення елементів орбіти.

Для підвищення точності визначення орбіти пропонується провести модернізацію апаратури та програмного забезпечення станції з метою зменшення похибки синхронізації та похибки визначення частоти радіосигналів. Також пропонується використовувати більш точні моделі як допплерівських вимірювань, так і руху супутників.

Keywords: Doppler's effect, radio beacon, low-orbit satellite.

\section{Introduction}

Over the last few years, ambitious projects have emerged to create global high-speed Internet satellite systems, such as (OneWeb Satellites, 2019; STARLINK. 2019; Telsat, 2019). According to our estimates, about 16000 of these satellites will be put into service by 2030 . Herewith 4500 of these satellites will have an orbit altitude of $350 \mathrm{~km}$ and 11500 satellites will have an orbit altitude of $850-1450 \mathrm{~km}$. It is estimated that there will be 20 or more satellites in the plane of one orbit. For comparison, the constellation of 27 GPS satellites is placed in 6 orbits of 4-5 satellites (slots) in each plane (Global Positioning System, 2019). Given the height of the orbits, the density of placing satellites in orbits of the Internet systems will be at least 50 times higher than in the GPS. However, in our opinion, slight deviations from the uniform distribution of the density of satellites in the orbit plane could significantly affect the quality of the Internet for end-users due to the corresponding significant displacement (given the orbit height) of the Earth's surface coverage. Therefore, a problem of constant independent high-precision determination of the position of low-orbit satellites will become even more urgent. A solution to the 
problem may be the creation networks of passive Doppler radars (stations) that determine the orbital position of satellites using the Doppler shift of frequency of radio signals emitted by the satellites. These could be either special monochromatic radio beacon signals (continuous wave) or non-harmonic broadband payload signals.

The Doppler station was developed and tested in the RI "MAO" to investigate the possibility of using such stations to clarity the orbit of low-orbit satellites (Bushuev, 2018). The station uses a compact high-tech receiver of up to 1766 $\mathrm{GHz}$ frequency range that greatly simplifies and reduces the cost of its hardware (GNSS-SDR, 2019). Initial orbits of tracked satellites are taken from (SPACE-TRACK.ORG, 2018). Model values of Doppler shift of frequency, obtained using the initial orbits, are used for searching radio signals emitted by tracked satellites and received by the station. It would be noted that 58 satellites were checked to search radio beacon signals. Radio beacons were detected for 18 satellites and 8 of them emit continuous waves.

\section{Upgrading the post-processing of observation da- ta obtained by the Doppler station}

There are two stages to clarify orbit elements of the given satellite: real time and post processing (Bushuev, 2018). In real time the radio signals are recorded in wavfiles using software defined radio and freeware program HDSDR (High Definition Software Defined Radio). Postprocessing includes analyzing the wav-files to determine the radial component of the satellite velocity $\left(v_{\mathrm{obs}}\right)$ and clarifying of the satellite orbital elements using $v_{\text {obs }}$. The program SatDoppler is used to determine $v_{\text {obs }}(t)$ as the function of time $t$, and program WinMNK takes into account $v_{\text {obs }}(t)$ to clarify of the satellite orbit elements.

The program SatDoppler has been significantly upgraded compare with (Bushuev, 2018). The upgraded program uses model values of Doppler shift of frequency $\left(f_{\text {dop }}\right)$ and correlation analyses for searching radio signals emitted by tracked satellites and received by the station. The model values of $f_{\text {dop }}$ are calculated using the initial orbit elements of tracked satellite downloaded from (SPACETRACK.ORG, 2018). Let $A_{o b s}(t, f)$ denote the amplitude of the received signal as a function of time $(t)$ and frequency (f). Let also $A_{\text {mod }}(t, f)$ denote the pattern equal 0 anywhere except some points where $A_{\text {mod }}=1$. The points where $A_{\text {mod }}=1$ correspond a function $f(t)$ that equal model values of radio beacon frequency at a moment $t$. Correlation function of $A_{o b s}$ and $A_{m o d}$ is calculate at first to find the radio signal emitted by the tracked satellite and received by the station. Herewith intervals of $t$ and $f$ for which function $A_{o b s}$ is determined must be greater than for function $A_{\text {mod }}$. The position $\Delta t$ and $\Delta f$ of the maximum of the correlation function is found next. The coordinates $\Delta t$ and $\Delta f$ give an offset of $A_{\text {mod }}$ relative to the beginning of $A_{\text {obs }}$. The desired signal is searched in the frequency range of $\pm 70 \mathrm{~Hz}$ near the points where $A_{\text {mod }}=1$ after the shift. So, the errors of synchronizing $(\Delta t)$ and determination of frequency $(\Delta f)$ of the received radio signal are also obtained as a result of the correlation analysis. The value of $\Delta f$ is due to the difference in the nominal frequency of the receiver reference generator from the valid one (Bushuev, 2018).

\section{Results of satellite orbit clarifying}

The results of the clarifying of the orbit of 10 satellites are shown in Table 1. Each satellite was tracked automatically by the Doppler station for at least 7 days. The obtained records of signals of satellite radio beacons were analyzed by SatDoppler and the measured values of the radial component of the satellite velocity $v_{\text {obs }}$ were determined. The WinMNK program used measured values of $v_{\text {obs }}$ to clarify orbit elements of the satellites. The model values of the radial velocity were calculated before $\left(v_{\mathrm{Bmod}}\right)$ and after ( $\left.v_{\text {Amod }}\right)$ clarifying of the satellite orbit. Herewith the orbit elements downloaded from space-track.org were used to calculate $v_{\text {Bmod. }}$ Means (Mean) and standard deviations (SD) of the difference $\Delta_{\mathrm{B}}=\left(v_{\text {obs }}-v_{\mathrm{Bmod}}\right)$ are shown in the columns "Before" of Table 1. The values of Mean and SD of the difference $\Delta_{\mathrm{A}}=\left(v_{\mathrm{obs}}-\right.$ $\left.v_{\text {Amod }}\right)$ are shown in the columns "After". The differences of absolute values of the mean and standard deviation of $\Delta_{\mathrm{A}}$ and $\Delta_{\mathrm{B}}$ are shown in columns "Diff |Mean|" and "Diff SD" of Table 1. The row "Total average" contains the average values of the data above it.

It follows from the data in Table 1 that the clarifying of the orbit elements of the satellites results in a slight decrease (by an average of $1.6 \mathrm{~m} / \mathrm{s}$ ) of both means and standard deviations of the difference of the measured and model values of the radial velocity of the tracked satellites.

It would be noted that the radio beacons of five satellites from Table 1 emitted non-harmonic broadband signals.

Table 1: Results of satellite orbit clarifying.

\begin{tabular}{|l|r|r|r|r|r|r|}
\hline \multirow{2}{*}{ Name } & \multicolumn{2}{|c|}{ Before } & \multicolumn{2}{c|}{ After } & \multicolumn{2}{c|}{ After-Before } \\
\cline { 2 - 7 } & Mean, $\mathrm{m} / \mathrm{s}$ & \multicolumn{1}{c|}{$\mathrm{SD}, \mathrm{m} / \mathrm{s}$} & Mean, $\mathrm{m} / \mathrm{s}$ & \multicolumn{1}{c|}{ SD, $/ \mathrm{s}$} & Diff $\mid$ Mean/, $\mathrm{m} / \mathrm{s}$ & \multicolumn{1}{c|}{ Diff SD, $\mathrm{m} / \mathrm{s}$} \\
\hline OSCAR-19 & -0.2 & 5.4 & -0.3 & 4.8 & 0.1 & -0.6 \\
\hline CUTE-1 & 0.2 & 2.2 & 0.0 & 1.8 & -0.2 & -0.4 \\
\hline CUTE-1.7 & -1.2 & 10.4 & -0.3 & 10.2 & -0.9 & -0.2 \\
\hline SEEDS & -0.1 & 3.4 & -0.2 & 3.0 & 0.1 & -0.4 \\
\hline KESEKI & 0.0 & 8.9 & 0.1 & 8.4 & -13.8 & -0.5 \\
\hline ITUPSAT-1 & 18.8 & 120.5 & 5.0 & 114.4 & 0.2 & -6.0 \\
\hline XIWANG-1 & -0.2 & 3.8 & -0.4 & 3.6 & 1.1 & -0.1 \\
\hline GOMX-1 & -0.5 & 28.7 & -1.6 & 22.9 & 0.0 & -5.8 \\
\hline AIST-2D & -0.6 & 8.4 & -0.6 & 7.6 & -2.7 & -0.8 \\
\hline TECHNOSAT & -5.4 & 24.7 & -2.7 & 23.3 & -1.6 & -1.3 \\
\hline Total average & 1.1 & 21.6 & -0.1 & 20.0 & -1.6 \\
\hline
\end{tabular}




\section{Conclusion}

The ground Doppler station of the RI "MAO" automatically tracked 10 low-orbit satellites for at least 7 days each. Herewith the radio beacons of five satellites emitted non-harmonic broadband signals. The orbit elements of these satellites have been clarified using measurements of the Doppler shift of frequency of their radio beacons. The regular (mean) and random (standard deviation) components of the difference (O-C) of measured and model values of radial velocity were calculated. A comparison of the regular and random components of $\mathrm{O}-\mathrm{C}$ was made, which showed their slight decreasing (in average at 1.6 $\mathrm{m} / \mathrm{s}$ ) after clarifying orbital elements.

The following is proposed to improve the accuracy of orbit determination:

- upgrading station's hardware and software to decrease synchronizing and frequency determination errors;

- using more accurate models as Doppler measurements, and the motion of satellites to clarify their orbit.

\section{References}

Bushuev F., Kaliuzhnyi M., Khalaley M. et al.: 2018, Odessa astronomical publications, 31, 167.

Global Positioning System [online] Available at: https://encyclopedia.thefreedictionary.com/Global+Po sitioning+System [Accessed 15 October 2019].

GNSS-SDR operation with a Realtek RTL2832U USB dongle DVB-T receiver, [online] Available at: http://gnsssdr.org/node/50 [Accessed 15 October 2019].

OneWeb Satellites [online] Available at: https://onewebsatellites.com/ [Accessed 15 October 2019].

SPACE-TRACK.ORG, [online] Available at: https://www.space-track.org/auth/login [Accessed 10 October 2018].

STARLINK [online] Available at: https://www.starlink.com/ [Accessed 15 October 2019].

Telsat [online] Available at: https://www.telesat.com/ services/leo/why-leo [Accessed 15 October 2019]. 